Jpn. J. Med. Mycol.

Vol. 25, 253-256, 1984

ISSN $0583-0516$

\title{
Microsporum canis による爪白癬と頭部白癬の合併例
}

\author{
藤田 和夫 本間 喜蔵 西本勝太郎 \\ 長崎大学医学部皮膚科学教室（主任：吉田彦太郎教授）
}

[受付：2月 20 日，1984 年]

\begin{abstract}
15 歳女子の後頭部, 左拇指爪に生じた Microsporum canis による白痽例を報告した. 飼猫が以前から 獣医により白痽の治療を受けて扔りこれが感染源となつた疑いが強い. 爪では基部に白濁があり，KOH 標本にて多数のやや短か目の菌系を認めた。

グリセオフルビン 1 日 $500 \mathrm{mg} 1$ カ月間内服を行い, 頭部白癬は 1 力月後, 爪白癬は 4 力月後治癒し た。自験例は M. canis による爪白癖の本邦報告第 1 例である.
\end{abstract}

Microsporum canis は犬・猫を主要宿主とする zoophilic dermatophytes の代表的な菌種であるが，人に は頭部白癬, ケルスス秃瘡, 体部白薩などを生ずるこ とが知られている。

今回われわれは 15 歳女子の頭部, 左拇指爪甲に発生 した $M$. canis 感染例を経験した.

本菌による爪白痽の報告は，われわれが検索した限 り，わが国の文献には見当らなかつた。

\section{症例}

患者：15 歳, 女子, 福岡県在住.

初診：昭和 57 年 5 月 11 日.

既往歴：13 歳時に帯状疮疹に罹患した以外特記す べきことはない。

家族歴：遺伝性疾患，アトピーなど特記すべきこと はない. 患者の皮疹発生約 1 力月前, 妹に皮疹を生じ, 他医にて体部白癖の診断のもとに治療をうけ，軽快し たという。

現病歷: 数力月来, 飼猫 (雑種) が獣医より白癬の 診断を受け，外用療法をつづけている由であつたが， この猫の菌学的検索を行なら機会は兄られなかつた。 初診の約 3 週間前, 前胸部の散在性小紅斑を $5 \sim 6$ 個 自覚, 獣医より自宅の飼猫に投与された猫用の外用剂 を使用した。当科受診時には紅斑はすでに軽快し薄い 色素斑を認めるの久で，確定診断はできなかつた。約

別刷請求先：藤田 和夫 厂 852 長崎市坂本町 7 番 1 号 長崎大学医学部皮膚科学教室
3 力月後, 後頭部に脱毛斑と, 左拇指爪基部寄りに白 濁が認められたため再診した。爪甲肥厚はなく，誘 因となるべき外傷などには気付かなかつたといら。

臨床所見：後頭部に約 $3 \times 2 \mathrm{~cm}$ 大の颗糠様落屑を 有する境界不鮮明な脱毛斑が存在する，痂皮，膿疮な ぞは認められなかつた (Fig. 1). 左拇指爪基部半分に 白濁と軽度の変形を認める。爪斥角質増殖，爪囲炎 はなかつた（Fig. 2).

検查所見：血液一般；RBC $429 \times 10^{4} / \mathrm{mm}^{3} ， \mathrm{Hb}$ $13.6 \mathrm{~g} / \mathrm{d} l$, Ht $36 \%$, Plt $23.6 \times 10^{4} / \mathrm{mm}^{3}$, WBC $4900 /$ $\mathrm{mm}^{3}$, 白血球分類; Seg $66 \%$, Lym $13 \%$, Mon $7 \%$, Eos $14 \%$, 肝機能 ; GOT $22 \mathrm{U} / l, \mathrm{GPT} 12 \mathrm{U} / l, \mathrm{LDH} 273$ $\mathrm{U} / l$.

\section{菌学的検索}

$\mathrm{KOH}$ 直接検鏡：脱毛部毛髪を毛外性に小型の胞子 が密にとりまき，典型的な microsporia 型の奇生所見 を示す (Fig. 3). 爪には，隔壁を有する比較的短い菌 糸を多数認めた (Fig. 4).

培養所見：爪，毛髪からの分離株はサブローブドウ 糖寒天培地上, 室温培養で共に同様の所見を呈した。 すなわち発育は速やかで, はじめ黄色, 後急速に白色 短䋐毛性となる平担なコロニーを形成した (Fig. 5). サブローブドウ糖寒天によるスライド培養では, 細胞 壁の厚い, 6 から 10 個の隔壁を有する長紡錘形の大分 生子を認めた (Fig. 6).

以上より本菌を Microsporum canis Bodin 1902 と 同定した。

治療执よび経過：上記の所見より，本症例を飼い猫 


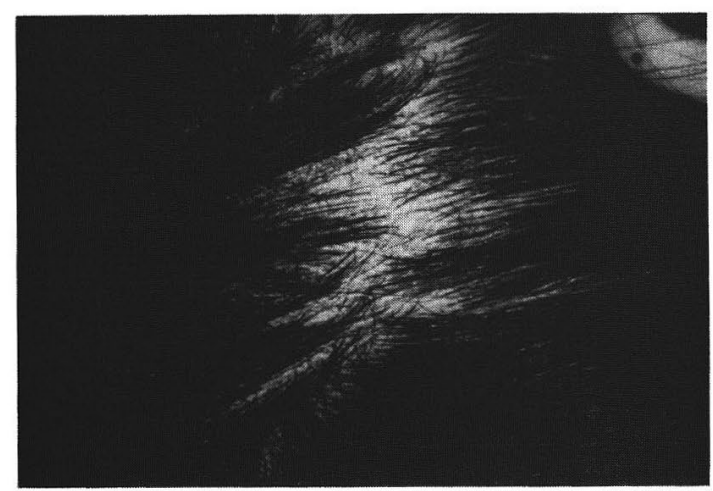

Fig. 1. Tinea capitis lesion with slight alopecia and scaling.

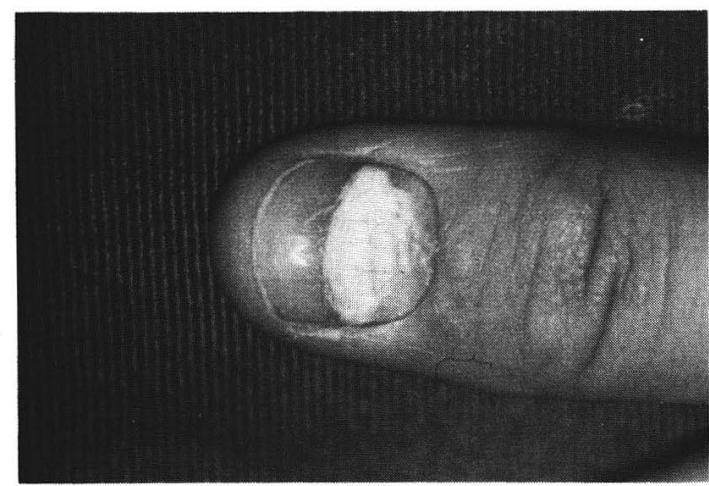

Fig. 2. Tinea unguium, discoloration of proximal half of the left thumb nail.

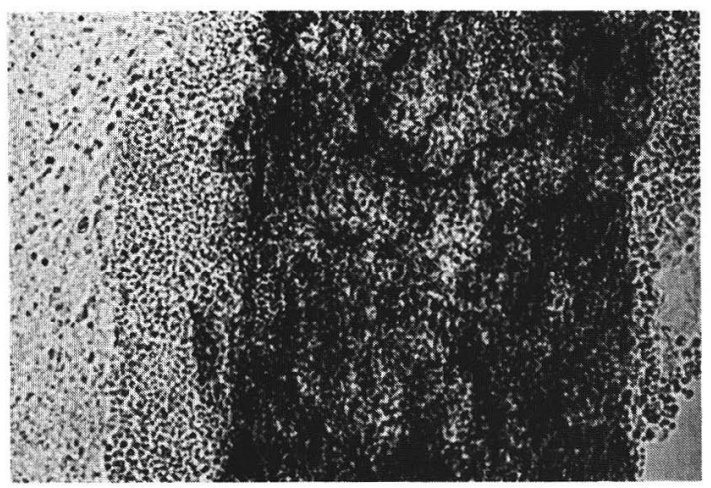

Fig. 3. $\mathrm{KOH}$-finding of the hair from tinea capitis lesion. $400 \times$.

より感染したと思われる爪白痽および頭部白癬と診断 し,グリセオフルビン 1 日 $500 \mathrm{mg}$ 内服と, 外用抗真菌 剤の併用を行つた。頭部白癬は約 1 カ月で治癒した。

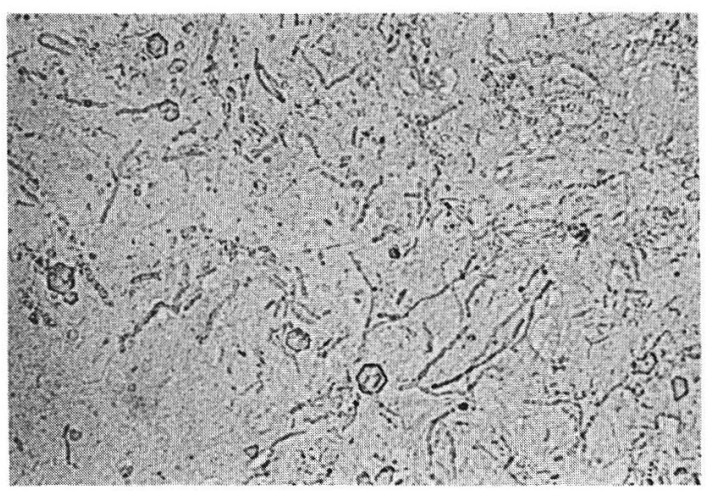

Fig. 4. KOH-finding of the nail. $400 \times$.

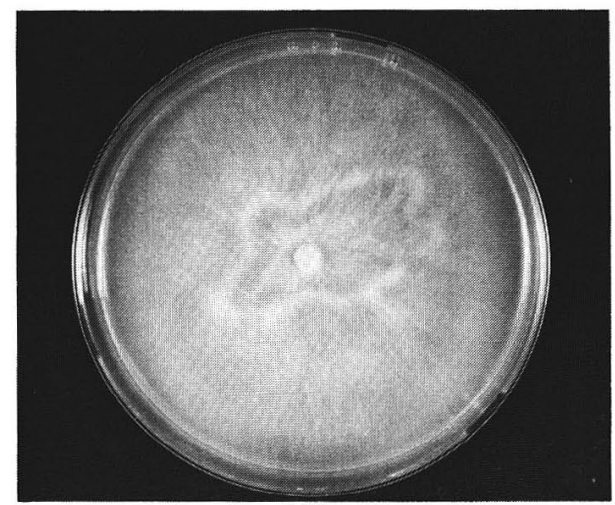

Fig. 5. Macromorphology of the causative fungi from tinea unguium lesion. Sabouraud dextrose agar, 3 weeks at room temperature.

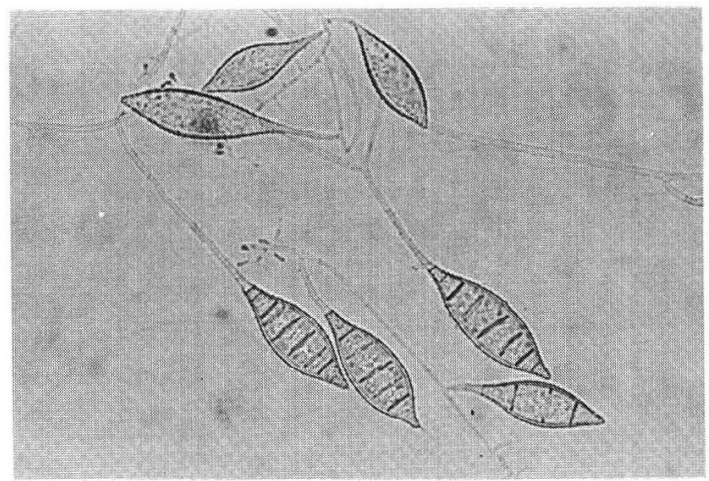

Fig. 6. Micromorphology of $M$. canis shown in Fig. 5. $400 \times$.

その後下峲のためグリセオフルビン内服は 1 力月間で 中止し, 以後硝酸ミコナゾールの外用のみを行つたが, 爪白癬も約 4 力月で治癒した。 


\section{考 察}

Microsporum canis はきわめて感染力の強いzoophilic dermatophyteである.わが国では 1934 年高 橋 ${ }^{1}$ により北海道に扔いて Microsporum sapporoense による小水疱斑状白癖として初めて報告されている。 その後は高月 ${ }^{2)}$, 小田島 $5^{3)}$, 青木ら ${ }^{4)}$, 小室ら ${ }^{5}$ 等の報 告がいずれも同地方のみでなされた。現在 $M$. sapporoense は M. canis の同義語とされている. 北海道以外 では 1952 年東京にて香川 ${ }^{6}$ が初めて本菌によるケル

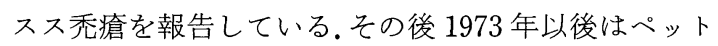
ブームに伴い全国的に流行が拡大し, 1975 年には九州 でも中原ら゙が第 1 例を報告している.

M. canis 感染症は 15 歳以下の小児では頭部白痽と 小水疮斑状白癬, 成人では小水疮斑状白痽の病型をと ることが多いといわ机ている8 ${ }^{8}$. 岩津ら ${ }^{9}$ とよる北海道 を除く日本各地の本症の集計では, 53 例中小水疮斑状 型 33 例 (62\%)，頭部白癬 4 例 (7.5\%)，ヶルスス秃 瘡 11 例 $(21 \%)$, 体部白瘫之頭部白癖の合併 2 例, 足 白癬 1 例とされている。北海道地方での久保ら ${ }^{10}$ の報 告では, 体部白獤型が $72 \%$ で最も多く, 頭部白痽 $17 \%$, ケルスス秃瘡 $8.6 \%$, 足白痽 $2.1 \%$ の順である。体部白 痽とケルスス秃瘡の合併も2例にみられている。これ らすべてを含めてこれまでわが国で爪白癄の報告はな く自験例の頭部白癬と爪白濓の合併はきわめて稀な例 と思われる。

Alteras ら ${ }^{11} の 1951$ 年より 1971 年までの M. canis 感染症の統計によれば，爪白㿏は 3 例で，いずれる足 白癬の合併があり，足白癬より二次的に感染した例と 考えられる。一般に爪白癬は周囲の汗疮状白准に続発 するものが多く，原発例はまれとされている ${ }^{12)}$. Tri-

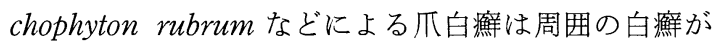
長期持続し，ついで爪甲の先端あるいは側縁より白濁, 変形などの変化をきたす。自験例は手白滻は認めず, 周囲病巣からの連続的な二次感染は考兄られない.又, 検索した範囲内での臨床検査, 及び既往歴には免疫不 全を思わせる所見はなかつた。われわれの症例の場合， 詳細は不明であるが，本人の他部位白癬（頭部白痽ま
たは体部白痽）あるいは飼い猫の白潅より爪甲に直接 接種され，発病したと思われる。

Microsporum gypseum による爪白痽は爪周囲病巣 より続発し，爪甲基部より白濁が生じるのが特徵であ $る^{12)}$. 本例も $M$. gypseum と同様，爪甲基部より白濁 が生じているが爪囲炎は欠如していた。これが $M$. canis に上る爪白痽の臨床的特徵かどうかは文献的に も症例が少なく, 今後の報告例の集積を待つて結論す べきことであろう。

本論文の要旨は, 日本皮膚科学会第 80 回四国地方会で発 表した、稿を終えるにあたり，御校閲をいただいた吉田彦太 郎教授に深謝する。

\section{文献}

1）高橋信吉：動物寄生性小芽胞菌の一新種に就て。 皮泌誌, 36：261-266， 1934.

2) 高月 晋：樺太に於ける皮膚系状菌病並びにその 病原菌に関する研究。日皮会誌, $40 ： 632-673$, 1946.

3）小田島重孝, 村田慶子, 浜田愛子, 海老原仁: 北海 道の白旗(第 1 報)。札医大紀要, $1: 79-87,1950$.

4）青木良枝, 村田慶子, 浜田愛子, 久保田麗子: 北海 道の白癄 (第 2 報)。札医大誌紀要, 2: 57-64, 1951.

5) Komuro, S., Aoki, Y. and Odashima, S.: On Microsporum sapporoense. 札幌医誌, $3: 1-13$, 1952.

6）香川三郎：札幌小芽胞菌並びに石膏様黄痽菌に因 るケルスス秃瘡について。皮泌誌，62：95, 1952.

7）中原哲士, 丸田宏幸, 皆見紀久男, 皆見省吾: 九州 地方に扮ける Microsprum canis 感染の第 1 例. 真菌誌, $15 ： 196,1974$.

8）白取 昭, 嶋崎 匡：Microsporum canis による kerion Celsi の 3 例。臨皮, 23：285-293，1969.

9）岩津郁希雄, 苅谷英郎：Microsporum canis 感染 症の母子例。臨皮，29：765-768，1975.

10）久保 等, 大河原章, 浜坂幸吉, 芝木秀臣: 北海道 に抢ける最近の M. canis 感染症について. 臨皮, 37 : 641-645, 1983.

11) Alteras, I. and Cojogaru, I.: Microsporum spp. in Tinea pedis. Sabouraudia $9: 126-128,1971$.

12) 本間嘉蔵, 西本勝太郎：Microsporum gypseum に よる爪白癄の 1 例。真菌誌, $22 ： 322-325,1981$. 


\section{A Case of Tinea Capitis and Tinea Unguium Caused by Microsporum canis}

Kazuo Fujita, Kizou Honma and Katsutaro Nishimoto

Department of Dermatology, Nagasaki University School of Medicine

(Director: Prof. Hikotaro Yoshida)

We report a case of tinea capitis and tinea unguium in a 15 year-old girl caused by Microsporum canis which was supposed to have been contracted from a pet cat.

The proximal half of her left thumb nail was discolored and numerous short hyphae were seen with potassium hydroxide preparation. $M$. canis was isolated both from hair and nail specimens. She was treated by oral grilseofulvin (500 mg per day) for one month and the scalp and nail lesions were healed after 1 and 4 months, respectively. This is the first reported case of onychomycosis caused by $M$. canis in Japan. 